\title{
RATIO ANSELMI REVISITED
}

\author{
MARCIN TKACZYK \\ John Paul II Catholic University of Lublin
}

\begin{abstract}
The proof of God's existence, known as Ratio Anselmi, is being analyzed. Four first-order theories are constructed to mirror versions of Anselm's reasoning. God's existence is shown to be provable in all of them. A traditional objection to the employment of a concept of God is overruled. And yet, Anselm's proof is eventually found to be incorrect. The error attributed to Anselm consists in an illegitimate use of the words "greater" and "conceivable", and is identified as quaternio terminorum or petitio principii, depending on circumstances. It is claimed that there is no direct way to improve the argument.
\end{abstract}

By Ratio Anselmi I understand the original proof of God's existence, provided by Anselm of Canterbury in chapter 2 of his work called Proslogion. The proof is usually regarded as the first attempt to prove God's existence a priori (ontologically) in history. My objective is to analyze that original proof as carefully as possible and evaluate it, as correct or not, on a precisely indicated ground. The so widely discussed and often formalized proof of chapter 3 of Proslogion as well as later ontological proofs are disregarded in this paper.

\section{INTERPRETATIONS}

What Anselm claims in chapter 2 of Proslogion is so difficult to understand that among scholars there is no agreement even regarding what kind of text one has to do with. M. Cappuyns, in his excellent summary ${ }^{1}$ of all

\footnotetext{
${ }^{1}$ M. Cappuyns, 'Largument de S. Anselme', Recherches de theologie ancienne et medievale, 6 (1934), pp. 313-330.
} 
studies concerning Ratio Anselmi until 1934, distinguishes four general kinds of interpretations or attitudes towards Anselm's text: logical, psychological, cosmological and theological. Cappuyns' summary seems to remain standing. Only in the first interpretation is Ratio Anselmi regarded as an argument (either sound or not) from some premises to a conclusion. In the psychological interpretation, Anselm simply affirms the fact of God's presence in mind, in the cosmological interpretation one has to do with a supplement to Monologion, and in the theological interpretation one has to do with an affirmation of the act of faith. It should be claimed that in this paper it is just assumed that Ratio Anselmi is an argument, an attempt to prove God's existence.

Even if one is convinced that Anselm's text is an argument, there is still a lot of philosophical interpretations of its meaning. Hence why Ratio Anselmi is so difficult to understand; I am going to analyze it on the purely logical level. The only non-vernacular meaning I am going to attribute to Anselm's statements is the meaning required by a formal structure of premises. To achieve such an objective, one must use a formal tool that is most transparent and uncontroversial. That would be the first order logic.

\section{PROSLOGION, CHAPTER 2}

In the chapter 2 of Proslogion Anselm concludes to God's existence as follows. God is a being than which nothing greater can be conceived. Suppose than there be no God in reality. By the supposition itself God exists in someone's mind and it is thinkable that God exists in reality. A being that exists in one's mind only is not a being than which no greater can be conceived, for its real existence is clearly conceivable. And real existence is something greater than existence in one's mind only. So, Anselm concludes, a being than which no greater can be conceived exists in reality. ${ }^{2}$ Anselm's argument rests on five premises. Four of them appear straightforwardly in Proslogion:

(P0) God is a being than which nothing greater can be conceived, (P1) a being is conceivable than which nothing greater can be conceived, (P2) if $x$ is conceivable, then $x$ is conceivable qua existent, (P3) $x$ qua existent is greater than $x$ qua non-existent.

\footnotetext{
${ }^{2}$ Anselm, Proslogion, chapter 2.
} 
There is another vital premise to be accepted:

(P4) if $x$ is conceivable, but not conceivable qua non-existent, then $x$ exists. The premise (P4) is hidden. As far as I am aware Anselm never admitted it, but the premise is inevitable. It will shortly be shown formally.

The premise (P0) may be found in Anselm's opening words: "and indeed, we believe that you are a being than which nothing greater can be conceived" ("et quidem credimus te esse aliquid quo nihil maius cogitari possit"). ${ }^{3}$ Some readers find here a definition of God, which is neither necessary nor obvious. The famous formula "a being than which nothing greater can be conceived" may be a definition as well as a partial description of God. It may even be just a postulate. It depends on whether the uniqueness of such a being is determined or not. This is why the indefinite article "a" is better and more safe English translation of "aliquid" than the definite article "the".

The premise (P1) is based on the fact that, even to deny God's existence, one simply must conceive of God. Anyone who takes the question of God into consideration makes some use of the concept of God. Anselm invokes the fool figured in the Holy Scripture, mostly in Psalms (cf. The Book of Psalms 14:1 and 53:1, in the Biblia Sacra Vulgata, the Latin version Anselm used, 13:1 and 52:1 respectively). The fool figures that there is no God: "is there no such nature [God], since the fool has said in his heart, there is no God?", says Anselm ("an ergo non est aliqua talis natura, qia dixit insipiens in corde suo: "non est Deus?»") ${ }^{4}$. Thus, according to Anselm, the fool determines God's conceivability: "but, at any rate, the very fool, when he hears of the being I speak of - a being than which nothing greater can be conceived - understands what he hears, and what he understands is in his understanding, although he does not understands it to exist" ("sed certe ipse idem insipiens, cum audit hoc ipsum quod dico: aliquid quo maius nihil cogitari potest, intelligit quod audit; et quod intelligit, in intellectu eius est, etiam si non intelligat illud esse") ${ }^{5}$. And again: "hence, even the fool is convinced that something, than which nothing greater can be conceived, exists at least in understanding; for, when he hears of it, he understands it, and whatever is understood, exists in understanding" ("convincitur ergo etiam insipiens esse vel in intellectu aliquid quo maius cogitari potest, quia

\footnotetext{
${ }^{3}$ Ibidem.

${ }^{4}$ Ibidem.

${ }^{5}$ Ibidem.
} 
hoc, cum audit, intelligit, et quidquid intelligitur, in intellectu est" ${ }^{6}$. So, if one affirms God's existence, they conceive of God, and if one denies it, they also conceive of God. All in all, God is conceivable. To avoid a kind of criticism most naive, it should be immediately noticed that Anselm is perfectly aware of an ontological commitment. Although he has no proper terminology, he determines straightforwardly the difference of existence and conceivability (existence in reality and existence in understanding). An artist, Anselm says, first conceives of what he is going to perform, and, until he does not perform it, it exists in the artist's understanding only. Hence, objects existing in an understanding only are just objects of the understanding. It was examined and explained by N. Malcolm: "Anselm [...] uses «intelligitur» and «in intellectu est» as interchangeable locution; the same holds for another formula of his: whatever is thought is in thought (quidquid cogitatur in cogitatione est)".?

In the premise (P2) a relation is affirmed between general conceivability and conceivability qua existent. First, according to Anselm, when a being is conceived of, it may be conceived either qua existent or qua non-existent. And those are two distinct thoughts. To conceive of an object is not the same as to conceive the object to exist: "for an object to be in understanding and to understand an object to be are two different things" ("aliud enim est rem esse in intellectu, alium intelligere rem esse"). ${ }^{8}$ But, Anselm continues, if an object is conceived at all it is also conceivable qua existent. You can always think an object to exist, provided you can think of the object: "even if [an object] exists in understanding alone, then it can be conceived to exist in reality" ("si enim vel in solo intellectu est, potest cogitari esse et in re"). ${ }^{9}$

According to the famous premise (P3), to exist in reality is something greater than to exist in understanding alone ("si enim vel in solo intellectu est, potest cogitari esse et in re, quod maius est"). ${ }^{10}$ The discussion dedicated to the passage just quoted is enormous. Plenty of ontological ideas came into being as regards the mysterious concept of Anselmian greatness. The problem is that Anselm seems to consider the hierarchy of greatness to be obvious, whereas for a contemporary philosopher it is

${ }^{6}$ Ibidem.

${ }^{7}$ N. Malcolm, 'Anselm's Ontological Arguments', The Philosophical Review, 69 (1960), pp. 41-62 (p.41).

${ }^{8}$ Anselm, Proslogion, chapter 2.

${ }^{9}$ Ibidem.

${ }^{10}$ Ibidem. 
hardly imaginable. I only refer to the features of the hierarchy formally determined by the premises themselves. No further philosophical analysis seems to me substantial for evaluation of the argument.

The hidden premise ( $\mathrm{P} 4)$ allows one to infer an object's existence from the inconceivability of its non-existence. It is a version of the assumption of some intelligibility of being. It is stated here that an object $x$ exists, provided $x$ is inconceivable qua non-existent, but conceivable generally. Although the premise is hidden, it may seem quite reliable. Actually, the whole science rests on the assumption of intelligibility of being.

\section{THE THEORY Pros}

To analyze Ratio Anselmi I will employ the first-order logic. In some formalizations modal logic is employed, which is even more controversial than Ratio Anselmi itself. Furthermore, Anselm's original thought is difficult to recognize in some formal constructions. They are at most inspired by Anselm, and more so by Descartes or Leibniz.

I provide four first-order theories of Ratio Anselmi: $\operatorname{Pros}, \operatorname{Pros}(a)$, $\operatorname{Pros}(b)$ and $\operatorname{Pros}(c)$ - where Pros stands for Proslogion. They differ in a position and interpretation of the premise (P0), the alleged definition of God. The crucial point of the formalization I deliver is the relativization of an object to an agent. It seems vital for Anselm's thought, and yet rarely respected. The first theory, Pros, is an extended and substantially improved version of a theory I provided in an earlier work of mine. ${ }^{11}$

The language of the theories I provide is typical for a first-order theory. In the alphabet there are the connectives of negation " $\neg$ ", conjunction “ $\wedge$ ”, disjunction “ $\vee$ ", implication “ $\rightarrow$ " and equivalence " $\equiv$ ", the identity sign " $=$ ", the universal quantifier " $\forall$ ", the existential quantifier " $\exists$ " and the unique existential quantifier (for exactly one, for one and only one) “ $\exists$ !", definable as follows:

$$
\exists ! x: A(x) \equiv \exists x: A(x) \wedge \forall x, y:(A(x) \wedge A(y) \rightarrow x=y) .
$$

Individual variables " $u$ ", " $w$ ", " $x$ ", " $y$ " and " $z$ " range over two domains possible agents and objects they may conceive of. I do not determine yet whether the agents are perfectly rational (logically omniscient) or not. The objects conceivable by the agents are mere objects of the agents' understanding, intensional objects. They need not - although they may

${ }^{11}$ M. Tkaczyk, 'Is the Ontological Proof of God's Existence an Ontological Proof of God's Existence?', Logic and Logical Philosophy, 16 (2007), pp. 289-309. 
- exist in reality. In the alphabet there are four specific predicates to form atomic formulas:

$$
\begin{array}{ll}
C(x, y) & -x \text { is conceived of by } y, \\
Q(x, y) & -x \text { is conceived of qua existent by } y, \\
H(x, y, u, w) & -x, \text { conceived of by } y, \text { is greater than } u, \text { conceived of by } w, \\
E(x) & -x \text { exists (in reality). }
\end{array}
$$

The letter " $C$ " stands for "conceived", the letter " $Q$ " stands for "qua existent", the letter " $H$ " stands for "hierarchy" and the letter " $E$ " stands for "exists". In some strengthened versions of Pros there will be an extra specific term, namely the individual term " $g$ " (for "God"), either primitive or defined. There may also appear a one-place derivative predicate " $G$ ", which is going to mean "is a god" or "is divine". If it is used, it will be introduced by a definition. Punctuation signs and formation rules are typical. So is the order of operations in absence of parentheses: $\exists, \forall, \neg$, $\wedge, \vee, \rightarrow, \equiv$. Tautologies are accepted as logical axioms, logical rules are applicable, free variables in theorems are universally quantified.

In the theory Pros, four specific axioms (A1)-(A4) are to be accepted, respectively to Anselm's premises (P1)-(P4). The first axiom:

(A1) $\exists x, y:(C(x, y) \wedge \neg \exists y, u, w: H(u, w, x, y))$

is a counterpart of Anselm's premise (P1). It is stated that there is such an object $x$ that $x$ is conceived of by some agent and no object conceived of by any agent is greater than $x$ conceived of by any agent. The second axiom:

$$
\text { (A2) } \quad C(x, y) \rightarrow \exists u: Q(x, u)
$$

is a counterpart of Anselm's premise (P2). If any object $x$ is conceived of by any agent, then, for some agent $u, u$ conceives of $x$ qua existent. The third axiom:

$$
Q(x, y) \wedge \neg Q(x, u) \wedge C(x, u) \rightarrow H(x, y, x, u)
$$

is a counterpart of Anselm's premise (P3). According to the axiom an object $x$ conceived by $y$ is something greater than the same object $x$ conceived of by $u$, provided $y$ conceives of $x$ qua existent and $u$ conceives of $x$ qua non-existent. There is another axiom:

(A4) $\quad \exists y: C(x, y) \wedge \forall y:(C(x, y) \rightarrow Q(x, y)) \rightarrow E(x)$

which is a counterpart of the hidden premise (P4). According to it an object $x$ exists (in reality), provided $x$ is generally conceived by some agent and no agent conceives of $x$ qua non-existent. Anselm's premise (A0) has no counterpart among axioms for the time being. Hence, we do 
not use the term "God" yet. The definition of a proof and of a theorem is typical. The theory Pros is consistent, which is important, for any formula is provable in an inconsistent theory. It is worth noting that many formalizations lack a proof of consistency. We are going to provide the proof of consistency of Pros, but we postpone it until we consider all the versions of Pros.

Within the confines of the theory Pros, the existence (in reality) is provable of an object than which nothing greater can be conceived. The derivation seems quite straightforward.

1. $\exists x, y:(C(x, y) \wedge \neg \exists y, u, w: H(u, w, x, y))$

axiom (A1)

2. $C(x, y) \rightarrow \exists u: Q(x, u)$ axiom (A2)

3. $Q(x, y) \wedge \neg Q(x, u) \wedge C(x, u) \rightarrow H(x, y, x, u)$ axiom (A3)

4. $\exists y: C(x, y) \wedge \forall y:(C(x, y) \rightarrow Q(x, y)) \rightarrow E(x)$ axiom (A4)

5. $\exists x:(\exists y: C(x, y) \wedge \exists u: Q(x, u) \wedge \neg \exists y, u, w: H(u, w, x, y))$

6. $Q(x, y) \wedge \neg Q(x, u) \wedge C(x, u) \rightarrow \exists y, u, w: H(u, w, x, y)$

7. $Q(x, y) \wedge \neg \exists y, u, w: H(u, w, x, y) \rightarrow \neg(\neg Q(x, u) \wedge C(x, u))$

8. $Q(x, y) \wedge \neg \exists y, u, w: H(u, w, x, y) \rightarrow(C(x, u) \rightarrow Q(x, u))$

9. $Q(x, y) \wedge \neg \exists y, u, w: H(u, w, x, y) \rightarrow \forall y:(C(x, y) \rightarrow Q(x, y))$

10. $\exists u: Q(x, u) \wedge \neg \exists y, u, w: H(u, w, x, y) \rightarrow \forall y:(C(x, y) \rightarrow Q(x, y))$

11. $\exists x:(\exists y: C(x, y) \wedge \forall y:(C(x, y) \rightarrow Q(x, y)) \wedge \neg \exists y, u, w: H(u, w, x, y)) \quad 5,10$

12. $\exists x:(E(x) \wedge \neg \exists y, u, w: H(u, w, x, y))$

In the row 12 the theorem appears to state that, for some $x, x$ exists (in reality) and no object conceived of by any agent is greater than $x$. That is the formal counterpart for Anselm's conclusion within the confines of the theory Pros.

Notice, nothing has been spoken of God explicitly thus far, the term "God" has not been used in any way yet, for no use has been made of Anselm's premise (P0). So there has been no prejudice made as regards a concept of God. Hence, the theory Pros, as well as the derivation just presented, may be considered as a general template to formalize Ratio Anselmi. A genuine formalization requires the complement of a counterpart of the premise (P0), and versions of the theory Pros depend on one's philosophical preferences regarding the premise in question. There are three considerable and reliable analyses of the premise (P0): (a) a definition of a singular term "God", (b) a definition of a predicate "is a god" or "is divine", and (c) a constraint, a partial characterization of God. Those will be the three versions of the theory Pros: $\operatorname{Pros}(a), \operatorname{Pros}(b)$ and $\operatorname{Pros}(c)$. 


\section{THE THEORY Pros $(a)$}

If one is convinced that a proper definition of God is provided in the premise (P0), the introduction of an individual term denoting God may be a considerable solution to state an explicit claim of God's existence. To do so, however, another premise is required in Ratio Anselmi, stating the uniqueness of the object than which nothing greater can be conceived:

(P5) there is at most one being than which nothing greater can be conceived. This is required for the consistency of a definition of an individual term. Together with the premise (P1) it secures the condition of existence and uniqueness to the individual term to be defined. The claim of the uniqueness of God is hardly questionable in the case of a Christian thinker and future bishop. Furthermore, it is admitted by Anselm explicitly in a succeeding passage of Proslogion ("quid es, nisi id quod summum omnium solum existens per seipsum, omnia alia fecit de nihilo?"), ${ }^{12}$ although it is not even mentioned in chapter 2. Nevertheless, it is a real strengthening of the theory. And anyone who thinks of future justification of premises should consider that profit and loss account. For it is a well known fact that to philosophically justify the uniqueness of God is a highly complicated matter even within the confines of Aquinas' ontology. However, if such price is to be paid, the new axiom:

(A5a) $\neg \exists z, u, w: H(u, w, x, z) \wedge \neg \exists z, u, w: H(u, w, y, z) \rightarrow x=y$

would serve as a counterpart for the premise (P5). It is stated here that any two objects, $x$ and $y$, than which nothing greater can be conceived, are identical. A theory Pros strengthened with the new axiom (A5a) will be called $\operatorname{Pros}(a)$. The axiom (A5a), together with the axiom (A1), with respect to the definition (1) allows to derive the existence and uniqueness condition:

$$
\exists ! x: \neg \exists y, u, w: H(u, w, x, y) .
$$

Hence, since (A1) and (A5a) are axioms of $\operatorname{Pros}(a)$, the formula (2) is a theorem of $\operatorname{Pros}(a)$. That legitimates a definition of the individual term as consistent:

$$
g=x \equiv \neg \exists y, u, w: H(u, w, x, y) .
$$

The term " $g$ " so defined stands for "God" and the definition is, of course, a counterpart of Anselm's premise (P0). It is stated here that God is the object than which nothing greater can be conceived. That would

\footnotetext{
${ }^{12}$ Anselm, Proslogion, chapter 5.
} 
complete the description of the theory $\operatorname{Pros}(a)$. As Pros, the theory $\operatorname{Pros}(a)$ is consistent. A derivation of Anselm's key theorem within the scope of $\operatorname{Pros}(a)$ may look as follows.

1. $\exists x, y:(C(x, y) \wedge \neg \exists y, u, w: H(u, w, x, y))$

axiom (A1)

2. $C(x, y) \rightarrow \exists u: Q(x, u)$ axiom (A2)

3. $Q(x, y) \wedge \neg Q(x, u) \wedge C(x, u) \rightarrow H(x, y, x, u)$ axiom (A3)

4. $\exists y: C(x, y) \wedge \forall y:(C(x, y) \rightarrow Q(x, y)) \rightarrow E(x)$ axiom (A4)

5. $\neg \exists z, u, w: H(u, w, x, z) \wedge \neg \exists z, u, w: H(u, w, y, z) \rightarrow x=y$ axiom (A5a)

6. $\exists ! x: \neg \exists y, u, w: H(u, w, x, y)$

7. $g=x \equiv \neg \exists y, u, w: H(u, w, x, y)$ definition based on row 6

8. $\exists y: C(g, y) \wedge \neg \exists y, u, w: H(u, w, g, y)$ 1,7

9. $C(g, y) \rightarrow \exists u: Q(g, u)$

10. $Q(g, y) \wedge \neg Q(g, u) \wedge C(g, u) \rightarrow H(g, y, g, u)$

11. $\exists y: C(g, y) \wedge \forall y:(C(g, y) \rightarrow Q(g, y)) \rightarrow E(g)$

12. $\exists y: C(g, y) \wedge \exists u: Q(g, u) \wedge \neg \exists y, u, w: H(u, w, g, y)$ 8,9

13. $Q(g, y) \wedge \neg Q(g, u) \wedge C(g, u) \rightarrow \exists y, u, w: H(u, w, g, y)$

14. $Q(g, y) \wedge \neg \exists y, u, w: H(u, w, g, y) \rightarrow \neg(\neg Q(g, u) \wedge C(g, u))$

15. $Q(g, y) \wedge \neg \exists y, u, w: H(u, w, g, y) \rightarrow(C(g, u) \rightarrow Q(g, u))$

16. $Q(g, y) \wedge \neg \exists y, u, w: H(u, w, g, y) \rightarrow \forall y:(C(g, y) \rightarrow Q(g, y))$

17. $\exists u: Q(g, u) \wedge \neg \exists y, u, w: H(u, w, g, y) \rightarrow \forall y:(C(g, y) \rightarrow Q(g, y))$

18. $\exists y: C(g, y) \wedge \forall y:(C(g, y) \rightarrow Q(g, y))$

19. $E(g)$

Hence, the theory $\operatorname{Pros}(a)$ is a little more complicated than Pros. But the reward is the theorem that appears in row 19: God exists (in reality). And, no matter what the traditional objection against Ratio Anselmi is, no logical error has been committed when introducing the term " $g$ " by means of the definition (3) (cf. row 7).

\section{THE THEORY $\operatorname{Pros}(b)$}

Instead of a term "God", a predicate "is a god" or maybe "is divine" could be introduced and defined to avoid the question of the uniqueness of God. If the derivative formula

$$
G(x)
$$

is to be read: $x$ is a god, the axioms (A1)-(A4) are sufficient and may remain unchanged. The definition:

$$
G(x) \equiv \neg \exists y, u, w: H(u, w, x, y)
$$


may complement the theory. That would be a counterpart for Anselm's premise (P0) here. It is stated here that any $x$ is a god if and only if the $x$ is a being than which nothing greater can be conceived. And no assumption regarding the number of such beings is being made. There may be exactly one god among objects of thought, as well as many gods, even infinitely many, or, finally, no gods whatsoever. Such a definition, if properly constructed, requires no further conditions to be consistent. The theory $\operatorname{Pros}(b)$ described like that is consistent. It is actually Pros itself, enriched with one derivative term.

To prove God's existence within the confines of the theory $\operatorname{Pros}(b)$ we proceed exactly as we do in the theory Pros, until row 12 (cf. page 6). Then proceed as follows.

$$
\begin{array}{lr}
\text { 13. } G(x) \equiv \neg \exists y, u, w: H(u, w, x, y) & \text { definition } \\
\text { 14. } \exists x:(E(x) \wedge G(x)) & 12,13
\end{array}
$$

The theorem proven in the theory $\operatorname{Pros}(b)$ claims, for some $x, x$ exists (in reality) and is a god (is divine). Which means, there is at least one god among existent objects. The introduction of Anselm's premise (P0) in that way is practically costless. As it has been already mentioned, Pros and Pros(b) are practically equivalent. On the other hand it is at least disputable to what degree Anselm's original philosophy has been faithfully recounted.

\section{THE THEORY Pros(c)}

There is a third solution. Anselm's premise (P0) may be considered a partial description of God rather than a normal definition. To say that an elephant is a mammal may not be a definition of an elephant, although it is a statement concerning the elephant. Similarly, to say that God is a being than which nothing greater can be conceived may not be a definition of God. Such a view is formalized in the theory $\operatorname{Pros}(c)$. The term " $g$ " is an individual name of God. However, it will not be defined, but rather included into the alphabet as a primitive term. So, the term " $g$ " may appear in specific axioms and it is at least partially characterized by the axioms. In the theory $\operatorname{Pros}(c)$, the axiom (A1) is to be replaced with another one:

$$
\text { (A1c) } \exists y: C(g, y) \wedge \neg \exists y, u, w: H(u, w, g, y) \text {. }
$$

The axiom (A1c) will serve for a counterpart of both premises (P0) and (P1): the first conjunct is a counterpart of the premise (P1), whereas the other one is a counterpart of the premise (P0). In the axiom it is 
stated that God is conceived of by an agent - the premise (P1) - and that nothing greater than God can be conceived of by any agent - the premise (P0). The axioms (A2)-(A4) remain unchanged and no further assumption is to be made. Again, the theory $\operatorname{Pros}(c)$ is consistent. The proof of God's existence within the confines of the theory $\operatorname{Pros}(c)$ may be conducted as follows.

$$
\begin{array}{lr}
\text { 1. } \exists y: C(g, y) \wedge \neg \exists y, u, w: H(u, w, g, y) & \text { axiom (A1c) } \\
\text { 2. } C(x, y) \rightarrow \exists u: Q(x, u) & \text { axiom (A2) } \\
\text { 3. } Q(x, y) \wedge \neg Q(x, u) \wedge C(x, u) \rightarrow H(x, y, x, u) & \text { axiom (A3) } \\
\text { 4. } \exists y: C(x, y) \wedge \forall y:(C(x, y) \rightarrow Q(x, y)) \rightarrow E(x) & \text { axiom (A4) } \\
\text { 5. } C(g, y) \rightarrow \exists u: Q(g, u) & 3 \\
\text { 6. } Q(g, y) \wedge \neg Q(g, u) \wedge C(g, u) \rightarrow H(g, y, g, u) & 1,5 \\
\text { 7. } \exists y: C(g, y) \wedge \forall y:(C(g, y) \rightarrow Q(g, y)) \rightarrow E(g) & 6 \\
\text { 8. } \exists y: C(g, y) \wedge \exists u: Q(g, u) \wedge \neg \exists y, u, w: H(u, w, g, y) & 10 \\
\text { 9. } Q(g, y) \wedge \neg Q(g, u) \wedge C(g, u) \rightarrow \exists y, u, w: H(u, w, g, y) & 11 \\
\text { 10. } Q(g, y) \wedge \neg \exists y, u, w: H(u, w, g, y) \rightarrow \neg(\neg Q(g, u) \wedge C(g, u)) & 12 \\
\text { 11. } Q(g, y) \wedge \neg \exists y, u, w: H(u, w, g, y) \rightarrow(C(g, u) \rightarrow Q(g, u)) & 8,13 \\
\text { 12. } Q(g, y) \wedge \neg \exists y, u, w: H(u, w, g, y) \rightarrow \forall y:(C(g, y) \rightarrow Q(g, y)) & 4,14 \\
\text { 13. } \exists u: Q(g, u) \wedge \neg \exists y, u, w: H(u, w, g, y) \rightarrow \forall y:(C(g, y) \rightarrow Q(g, y)) & \\
\text { 14. } \exists y: C(g, y) \wedge \forall y:(C(g, y) \rightarrow Q(g, y)) & \\
\text { 15. } E(g) &
\end{array}
$$

The theorem derived in row 15 refers to God's existence straightforwardly. The theory $\operatorname{Pros}(c)$ combines the simplicity of the theory Pros with the efficiency of the theory $\operatorname{Pros}(a)$. That seems to be quite a recommendation, but still the choice between the presented variants of the theory Pros remains open and should depend mainly on philosophical investigations.

\section{FORMAL FEATURES OF THE THEORIES}

As has already been mentioned a few times, all the formal theories we presented, i.e. $\operatorname{Pros}, \operatorname{Pros}(a), \operatorname{Pros}(b)$ and $\operatorname{Pros}(c)$, are consistent. It may be easily shown by means of interpretation in arithmetic of natural numbers including zero. To transform formulas of the theories in question into formulas of arithmetic, read

$$
\begin{array}{ll}
C(x, y) & \text { as } x=y, \\
Q(x, y) & \text { as } x=y, \\
H(x, y, u, w) & \text { as } x>y+u+w
\end{array}
$$


and

$$
E(x) \quad \text { as } x=x .
$$

Furthermore, regarding the theory $\operatorname{Pros}(c)$ only, read " $g$ " as zero. Under such interpretation, all the axioms in question - (A1), (A1c), (A2), (A3), (A4) and (A5a) - turn out to be true statements of arithmetic. Derivative terms - " $g$ " in $\operatorname{Pros}(a)$ and " $G$ " in $\operatorname{Pros}(b)$ - do not require interpretation, for the respective definitions - (3) and (4) - are formally correct.

A similar interpretation shows the hidden premise (P4) to be vital. As it has been claimed, although the premise (P4) does not appear in Anselm's text explicitly, it is definitely unavoidable in the reasoning. So, if one reads

$$
\begin{array}{ll}
C(x, y) & \text { as } x=y, \\
Q(x, y) & \text { as } x=y, \\
H(x, y, u, w) & \text { as } x>y+u+w
\end{array}
$$

and

$$
E(x) \quad \text { as } x \neq x
$$

the axioms (A1), (A2) and (A3) are transformed into true statements of arithmetic, whereas the axiom (A4) is transformed into a false statement of arithmetic. Similarly Anselm's theorem of God's existence, derived in the theory Pros (cf. the derivation on the page 6, row 12) is also transformed into a false statement of arithmetic. This proves that both the axiom (A4) and the theorem derived are independent from axioms (A1), (A2) and (A3). So, the axiom (A4) is substantial. Analogical considerations show the premise $(\mathrm{P} 4)$ to be inescapable in all versions of the theory Pros.

\section{THE CONCEPT OF GOD}

The chief objection voiced commonly to Ratio Anselmi concerns the way Anselm makes use of the concept of God. It is claimed to be illegitimate to conclude from a definition or a concept of an object to the existence of that object ("lobjection calassique contre l'argument de S. Anselme est qu'il fait sortir l'existence de la pens' $e$ "). ${ }^{13}$ And what Anselm did appears to be exactly such a conclusion, so he seems to prejudice the case in favour of God's existence at the starting point. Of course, the premise (P0) sits in the dock.

${ }^{13}$ E. Gilson, 'Sens et nature de l'argument de Saint Anselme', Archives d'histoire doctrinale et litteraire du moyen age, 9 (1934), pp. 5-51 (p. 6). 
The objection was raised immediately, when Anselm had issued Proslogion, by a mysterious monk called Gaunilo of Marmoutiers, the author of Liber pro insipiente. Gaunilo points out a concept of a perfect desert island, lost somewhere in oceans and absolutely unknown ("aiunt quidam alicubi oceani esse insulam, quam [... f fabulantur multo amplius quam de fortunatis insulis fertur, diuitiarum deliciarumque omnium inaestimabili ubertare pollere, nulloque possessore aut habitatore uniuersis allis quas incolunt homines terris possidendorum redundantia usquequaque praestare"). ${ }^{14}$ If Anselm's reasoning was correct, no one, who understood the concept, might doubt such an island to exist in reality. For an existent island is greater (i.e. better) than a nonexistent one, and so the non-existent one is not perfect ("non potest ultra dubitare insulam illam terris omnibus praestantiorem uere esse alicubi in re [...] quia nisi fuerit, quaecumque alia in re est terra, praestantior illa erit, ac sic ipsa iam a te praestantior intellecta praestantior non erit"). ${ }^{15}$

The objection took classical shape in Contra Gentiles by Thomas Aquinas. He claimed clearly that there was no legitimate conclusion to be drawn from a concept to existence in reality, although there may be a legitimate conclusion drawn from a concept to existence in understanding (i.e. conceivability or conceivability qua existent). So, Anselm's reasoning must not be correct ("eodem enim necesse est poni rem et nominis rationem; ex hoc autem quod mente concipitur quod profertur hoc nomine "deus» non aequitur Deum esse, nisi in intellectu [...] et ex hoc non sequitur quod sit aliquid in rerum natura, quo non majus cogitari non possit"). ${ }^{16}$ The objection of Gaunilo and Aquinas was to be repeated over and over again during the following centuries, but no one put it better than they.

Although Gaunilo and Aquinas' objection shows a probably right feeling that something is wrong about Ratio Anselmi and that it has something to do with the concept of God, the objection thus voiced is certainly illegitimate. Nothing, but adversaries' feelings, may prohibit one from using definitions in proofs of the existence of any objects. On the contrary, no proof can be conducted until it has been determined, at least partially, what the object of the proof is. For instance, to prove that in any set of natural numbers there is the smallest one, it is necessary to

\footnotetext{
${ }^{14}$ Gaunilo of Marmoutiers, Liber pro insipiente, chapter 6.

${ }^{15}$ Ibidem.

${ }^{16}$ Thomas Aquinas, Contra Gentiles, I, 11.
} 
know what a natural number and the smallest number in a set is. The objection I speak of may be easily and immediately discredited by a brief observation of any of Aquinas' proofs of God's existence (the so called Five Ways). Each of those five proofs ends with a similar statement: and that is what everyone calls God. For example, at the end of the kinetic argument (ex motu) one can read: "therefore it is necessary to arrive at a first mover, put in motion by no other; and this everyone understands to be God" ("ergo necesse est devenire ad aliquid primum movens, quod a nullo moveatur, et hoc omnes intelligunt Deum"). ${ }^{17}$ Such a phrase is perfectly analogical to that of Anselm: "truly there is, then, a being than which nothing greater can be conceived to exist, that it cannot even be conceived not to exist; and this being you are, o Lord, our God" ("sic ergo vere est aliquid quo maius cogitari non potest, ut nec cogitari possit non esse; et hoc est tu, Domine Deus noster"). ${ }^{18}$

So, Aquinas makes no less a use of a concept of God than Anselm. The only difference is that Anselm puts it forward at the beginning, while Aquinas delays it to the end. And the difference is a matter of writing style only. Notice, there is no difficulty whatsoever to rephrase Anselm's proof in, say, Aquinas' style or contrarily.

To rephrase Anselm's proof, consider the theory Pros. Within its confines, a theorem has been derived in row 12 :

$$
\exists x:(E(x) \wedge \neg \exists y, u, w: H(u, w, x, y))
$$

with no use of any concept of God whatsoever. It is now legitimate to add the definition (4) in row 13, and immediately derive the statement of the existence of a god:

$$
\exists x:(E(x) \wedge G(x)),
$$

like in the theory $\operatorname{Pros}(b)$. And if one is ready to strengthen the theory Pros by the addition of the axiom (A5a), to the effect of the uniqueness of the being than which nothing greater can be conceived, one can, again, derive the theorem (5) with no use of any concept of God. And finally, on the base of (A5a) and (5), the definition (3) may be introduced properly, which allows us to derive the existence of God:

$$
E(g) \text {, }
$$

like in $\operatorname{Pros}(a)$. And remember, in the theory $\operatorname{Pros}(c)$ Anselm's reasoning is absolutely definition-free. So, generally, like Aquinas, Anselm may

\footnotetext{
${ }^{17}$ Thomas Aquinas, Summa Theologica, I, 2, 3.

${ }^{18}$ Anselm, Proslogion, chapter 3.
} 
forget any concept of God and argue for the existence of an object than which nothing greater can be conceived. And, like Aquinas, finally, once everything has been done, he may call the object God on behalf of all of the human genus.

On the other hand, any Aquinas' proof may be immediately rephrased to mirror Ratio Anselmi. Consider Aquinas' kinetic proof ${ }^{19}$ in a slightly new version, say, Anselmian style. "Who are you, o God? We believe you are a first mover, put in motion by no other. Is there no such an object, since the fool has said in his heart, there is no God? But, if there is no first mover, there is no motion whatsoever, for whatever is in motion, is put in motion by another, and that by another again, and this cannot go on to infinity. So moving things do not actually move, but this is not possible." If you rephrase Aquinas' argument slightly like that, it appears to derive existence from a definition no less than that of Anselm.

A transformation of the objection I speak of concerns the ontological commitment of the first order logic. It is sometimes argued that any use of the existential quantification prejudices in favour of the existence of the object. That is a pure misunderstanding, for the existence expressed by the existential quantification is exactly belonging to the domain of quantification and nothing more, and the domain must not be empty. This does not determine either real or any other form of the existence of the objects the domain consists with. Imagine, for instance, two mathematicians: Tweedledum and Tweedledee. Tweedledum is a Platonist while Tweedledee is a nominalist. They may perfectly agree that there exists a natural quotient of the numbers 27 and 9, and yet in Tweedledum's view numbers exist, whereas in Tweedledee's view they do not. Similarly, existential quantification in Anselm's proof - at least if formalized like the theory Pros and its versions - determines that there is at least one object of understanding, i.e. at least one object is conceivable, not that it exists in reality.

\section{THE WORD “GREATER”}

Neither presence nor location of a definition is vital for evaluation of a proof. However, the content of the definition is vital, unless one has to do with a purely terminological convention. And it may be judged adequate or not, and hence, affirmed or rejected.

${ }^{19}$ Thomas Aquinas, Summa Theologica, I, 2. 3. 
When the existence (or non-existence) of God is being proved, the issue is not an arbitrary object to be called God or anything else, by mere convention, for short. The issue is rather some object people think and speak of in common vernacular. And those thinking or speaking of God have at least an indefinite feeling of what God approximately is. What is generally in force refers especially to Jewish, Christian and Muslim thinkers. Particularly Christians face the challenge to justify the existence of God that is spoken of in the Nicene Creed.

Consider the premises (P0) and (P3). In the latter it is stated that to exist is something greater (in a sense) than not to exist. Philosophers have put a lot of effort into the elucidation of the concept of greatness, achieving rather modest success. However, philosophical views concerning greatness are not substantial and may be disregarded without loss. It is enough to take into account the fact that existence is included into some hierarchy of being in a way described strictly in the axiom (A3). The term "greater" may be understood in any sense, provided the axiom (A3) is satisfied.

Proceed now to the premise (P0), according to which God is a being than which nothing greater can be conceived. Together with the premise (P3), that means God is more similar to existent objects than to nonexistent ones. God stands closer - in the sense of the premise (P3) - to existent than to non-existent objects. Now, if one believes in God, the maker of all that is, seen and unseen (cf. the Nicene Creed), the premise (P0) is a considerable view. However, if one is an atheist, one clearly must not accept the premise (P0). Atheism simply consists of the notion that the God that Christians believe in is not a being than which nothing greater can be conceived (in the sense of the premise in question). According to any atheist, any existing object, including the piece of paper you read, is greater than God. For God simply does not exist. Hence, the premise (P0) simply states what is to be concluded to. Such an error is usually called petitio principii.

On the other hand, if the premise ( $\mathrm{P} 0$ ) governs the term "greater", the Christian God is by definition a being than which nothing greater can be conceived. That concept would be something close to the concept of the Almighty of the Nicene Creed. According to Cappuyns this is just the case; namely, the definition of God as a being than which nothing greater can be conceived is most obvious and most common ("admise par tout 
le monde et, en realite, tautologique"). ${ }^{20}$ An atheist is ready to accept such a concept of God, for it is deeply rooted in common vernacular. However, in that case the atheist simply must reject the premise (P3), for at least in one case a non-existent being - namely, God as understood in the premise (P0) - is greater than an existent object - namely any existent being. And again, it is no sign of the atheist's malice; it is just the content of the claim of atheism. Similarly, petitio principii has been committed in Ratio Anselmi. Thomas Aquinas was probably quite close to revealing it. Arguing against Anselm, Aquinas wrote that to state that something greater can be thought than anything given in reality is a difficulty only to a person who admits that there is in reality something than which nothing greater can be conceived ("non enim inconveniens est, quolibet dato vel in re, vel in intellectu, aliquid majus cogitari posse, nisi ei qui concedit esse aliquid, quo majus cogitari non possit in rerum natura"). ${ }^{21}$ It might be the case that Aquinas, having accepted the premise (P0), understood that (P3) is simply illegitimate, false under such a sense of the word "greater".

There is one more eventuality. Perhaps the term "greater" appears in Ratio Anselmi in at least two different meanings. Once, in the premise (P0), in a sense close to the common vernacular, and again in the premise (P3), in the technical sense, rather obscure, but described sufficiently in the premise. Well, such an error is called traditionally quaternio terminorum. No other policy seems to be imaginable. All in all, unfortunately, Anselm's proof proves nothing.

\section{THE WORD “CONCEIVE”}

There is another, quite similar, error in Ratio Anselmi. It is connected with the expressions " $x$ is conceivable" and " $x$ is conceivable qua existent". They have been formalized as " $\exists y: C(x, y)$ ", which means that some agent (e.g. the fool) conceives of $x$ in a way, and " $\exists y: Q(x, y)$ ", which means that some agent conceives of $x$ qua existent, respectively. Conceivability may be understood in several ways, but in Anselm's proof, because of the premise (P2), it must be a way that includes possibility somehow. Objects of inconsistent descriptions, like a square circle, should be considered as inconceivable. It may be questioned whether or not physically impossible

${ }^{20}$ M. Cappuyns, 'L'argument de S. Anselme', p. 324.

${ }^{21}$ Thomas Aquinas, Contra Gentiles, I, 11. 
or similar objects - like a cheese moon - are conceivable in that sense. Fortunately, that question may be disregarded here.

The crucial question to be posed refers to the domain of agents that the variables range over. There are two eventualities: either all agents are admissible, including logically fallible ones, or only those that are ideal, i.e. those perfectly rational. The point is, whether all agents being considered enjoy logical omniscience, i.e. the unrestricted ability to see logical consequences and the absolute freedom of logical errors (a nightmare of all those occupied with epistemic logic). Now, look through the two eventualities.

Suppose first, all agents are perfectly rational. In such a case the premise (P1) is completely unjustified. Both the Biblical fools and sincere believers appear to conceive of God, for they think and speak of him. However, perhaps God is actually inconceivable, but they do not realize it. They may not be able to see or correctly judge all the logical consequences of the description of God. They may not be able to see, say, inconsistencies in the description of God, like Gottlob Frege had not noticed inconsistencies in his description of sets, until he received the famous letter from Bertrand Russell. So, in such a case it would only appear that God is conceivable, because an irrational agent often judges by appearances. No perfectly rational agent would ever judge such a God as being conceivable - at least in a sense meeting the premise (P2). In such a case Anselm must be reproached with petitio principii.

Consider in turn the other eventuality. Suppose irrational, or at least fallible, agents are admissible. In such a case the premise (P1) is certainly justified. However, the hidden premise (P4) is not only unjustified, but it is certainly false. (And I proved that the axiom (A4), the counterpart of the premise (P4) is inevitable, cf. page 11.) It is stated in the premise in question that an object $x$ exists (in reality), provided $x$ is conceivable, but inconceivable qua non-existent. That would be a kind of principle of the rationality of being. Now, suppose an object $x$ is conceived of by a single irrational agent $a$, who cannot see the impossibility of its existence. And $a$ conceives of $x$ qua existent. No other agent conceives of $x$, especially no perfectly rational agent ever conceives of $x$. Clearly, due to the agent $a$, the first conjunct of the antecedent of the axiom (A4) or the premise (P4) is satisfied. And so is the other conjunct, for there is no agent which conceives of $x$ qua non-existent. Nevertheless, $x$ must not exist. So, if fallible agents are admissible, the premise (P4) is not justified or even strictly false. That is, however, petitio principii once again. 
Gaunilo took some note of the problem of the abilities of the agents when he claimed that no proof of God's existence would have been necessary if God had been truly inconceivable qua non-existent ("uix umquam poterit esse credibile, cum dictum et auditum fuerit istud, non eo modo posse cogitari non esse, quo etiam potest non esse deus; nam si non potest: cur contra negantem aut dubitantem quod sit aliqua talis natura, tota ista disputatio est assumpta"). ${ }^{22}$ And it was John Duns Scotus who first claimed clearly that conceivability in Anselm's sense is not sufficient to justify the possibility of God's existence. ${ }^{23}$

\section{CONCLUSIONS}

On the purely formal level, Ratio Anselmi is a piece of proper deduction. No illegitimate use of a concept of God is being made. However, it is not sound and proves nothing except entailment between premises and conclusions of a sort. The meaning of the terms "greater" and "conceived" is indefinite, which causes the collapse of the whole proof. There is no direct remedy, for the meaning of a term required by one premise is excluded by the other and conversely. Some medieval thinkers, like Aquinas, Gaunilo and Duns Scotus, might have been partially aware of some of those problems. However, none of them was able to phrase them in an adequate way. Perhaps it is the formalization which enables us to see assumptions and other interrelations between premises and other theorems, provided the formalization is accurate enough and the formal tool employed is transparent.

\section{BIBLIOGRAPHY}

Anselm of Canterbury, 'Proslogion', in: Sancti Anselmi Cantuariensis archiepiscopi Opera omnia, vol. 1, ed. O. F. S. Schmitt (Seccovii, Edinburgi: Nelson, 1946), pp. $93-122$

Cappuyns, M., 'Largument de S. Anselme', Recherches de theologie ancienne et medievale, 6 (1934), pp. 313-330

Duns Scotus, J., Ordinatio, ed. L. Wadding (Lyon: Durand, 1639. Reprint: Hildesheim: G. Olms, 1968)

Duns Scotus, J., Reportata Parisiensia, ed. by L. Wadding (Lyon: Durand, 1639. Reprint: Hildesheim: G. Olms, 1968)

${ }^{22}$ Gaunilo, Liber pro insipiente, chapter 2.

${ }^{23}$ John Duns Scotus, Ordinatio, I, 2, 1; John Duns Scotus, Reportata Parisiensia, I, 3, 2. 
Gaunilo of Marmoutiers, 'Liber pro insipiente (quid ad heac respondeat quidam pro insipiente)', in: Sancti Anselmi Cantuariensis archiepiscopi Opera omnia, vol. 1, ed. O. F. S. Schmitt (Seccovii, Edinburgi: Nelson, 1946), pp. 125-129

Gilson, E., 'Sens et nature de l'argument de Saint Anselme', Archives d'histoire doctrinale et litteraire du moyen age, 9 (1934), pp. 5-51

Malcolm, N., 'Anselm's Ontological Arguments', The Philosophical Review, 69 (1960), pp. 41-62

Aquinas, T., Summae contra Gentiles Libri Quattuor (Romae: Forzani, 1924)

Aquinas, T., Summa Theologica (Romae: Forzani, 1924)

Tkaczyk, M., 'Is the Ontological Proof of God's Existence an Ontological Proof of God's Existence?', Logic and Logical Philosophy, 16 (2007), pp. 289-309 